\title{
回転速度一定制御モータ推進システムにおける プロペラ周囲気泡とスラスト変動の特性評価*
}

\author{
大 出 剛 ** \\ 波津久 達 也** \\ 賞 雅 寛 而*** \\ 井 原 智 則**
}

\begin{abstract}
Characterization of Near-Propeller Bubbles and Thrust Fluctuation in a Constant Rotational Speed Control Motor Propulsion System
\end{abstract}

By Tsuyoshi ODE, Tomoji TAKAMASA, Tatsuya HAZUKU, Tomonori IHARA

In this study, we aimed to improve the propulsion efficiency of the motor drive system by suppressing the load fluctuation caused by the generation of air bubbles around the propeller. Experiments were conducted to verify the detection of air bubbles around the propeller using status monitor signals from the motor drive and the correlation between the monitor signals and the thrust in the $\mathrm{AC}$ motor drive system, when driven by the constant rotational speed control method. Experimental data such as the motor power fluctuation were compared, and verified by comparison with previously reported experimental results. This established that the correlation between the monitor signal from the motor drive and the bubble generation and quantity around the propeller, as well as the thrust, can be expressed using the propeller characteristic equation and the motor characteristic equation for the motor drive system when driven by the constant rotational speed control method. We showed that the monitor signal of the motor drive system can be considered a sensing signal, and used to stabilize the motor power and thrust fluctuations in the motor drive system when driven by either the constant torque control or the rotational speed control method.

\section{1. はじめに}

プロペラ空気吸い込みやキャビテーションなどは, プロペラのスラスト, 推進効率を大きく低減させるだ けでなく, 騷音と振動を発して機関や推進器にダメー ジを与える 1). 空気吸い込み中にプロペラに作用する 力の調查や空気吸い込みの発生がプロペラ没水深度お よびプロペラ負荷のような運転パラメータにどのよう に依存寸るか報告されている2)3. しかしながら, 空気 吸い込み現象は複雑な現象で, 発生メカニズムなど理 論的解明が未だなされていない 4). 空気吸い込みによ る推進損失は，半経験的手法を用いて説明されている が, 変動負荷の計算方法や物理現象の基礎を知る方法 はほとんどない5)。大出らは，前報677において，交流 モータドライブシステムをトルク一定制御で駆動させ, ドライブシステムからの状態出力信号が, プロペラ周

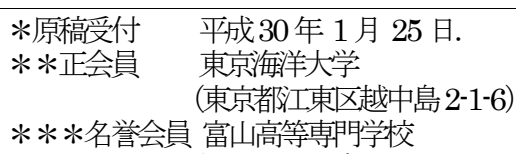

囲状態やスラスト変動を精度よく高速に検知すること が可能であることを検証し，回転速度モニター信号か ら, 回転速度とプロペラ周囲気泡の相関, その時の回 転速度とスラストの相関を，プロペラ特性式で説明が できることを示した．本報告では，交流モータドライ ブシステムを回転速度一定制御方式にて駆動させ，ド ライブシステムからのトルクモニター信号から，トル クとプロペラ周囲気泡の相関，その時のトルクとスラ ストの相関を実験から得た測定值とプロペラ特性式か ら理論的に検証する. また, 前報 677で報告したトルク 一定制御方式での実験結果を整理して示し，回転速度 一定制御方式での実験結果との比較, 相関を検証する. さらに，双方の制御方式におけるモータ出力変動とス ラスト変動を比較，検証する.

\section{2. 実験}

\section{1. 実験装置と実験方法}

実験は，東京海洋大学の単一インペラー式水平循環 型の大型回流水槽 8) にて, 前報 677)でのトルク一定制御 方式の実験と同じ装置で，プロペラ没水深度，回流速 
度など同じ実験条件で行った. Fig. 1 のブロック線図 で示すようモータドライブシステム，電子制御ユニッ ト, 推進装置, ロードセル, 高速度カメラ, 電力計と データロガーで構成する実験装置を用いている（詳細 は前報 6$)$ )。実験装置は, 気泡吸い込みによるプロペラ 負荷が大きいボラードプルに近い状態になるよう，推 進装置を回流水槽に固定し, また, プロペラ没水深度, 回流速度とプロペラ径を，それぞれ，185 mm，0.5 $\mathrm{m} / \mathrm{s}$ と $0.187 \mathrm{~mm}$ に設定した. 解析に用いる計測デー タは, 起動後, 回転速度が一定状態に達した後のプロ ペラ周囲気泡発生時のデータとした ${ }^{7)}$.

\section{2. モータ制御におけるプロペラ特性の理論的相関}

Fig. 2 に実験に使用した交流モータドライブのト ルク-回転速度特性 10) とプロペラのトルク-回転速度特 性を示す.

$$
\text { モータ出力 } P_{m}(\mathrm{~W}) \text { は, }
$$

$$
P_{m}=T q \cdot 2 \Pi n
$$

で表され, $T q(\mathrm{~N})$ はトルク,$n\left(\mathrm{~s}^{-1}\right)$ は回転速度である 7).

回転速度一定制御方式においては，回転速度指令を 与えるとモータのトルクは負荷特性に対応したトルク になる. 図中で回転速度一定值 $n_{1}$ が出力される時, 負荷特性が曲線 1）の場合モータトルクは $T q_{1}$ にな り, 負荷特性が変化して曲線 2) になると, モータ回 転速度は変わらず，トルクは変化した特性曲線 2) 上 のトルク $T q_{2}$ になる. この時モータ出力は, 式 (1) よ り $\left(T q_{2}-T q_{1}\right) \cdot 2 \Pi n_{1}$ 分降下寸ることになる.

一方，トルク一定制御方式においては，トルク指令 を与えるとモータの回転速度は負荷特性に対応した回 転速度になる. 図中で示すようトルク一定値 $T q_{1}$ が

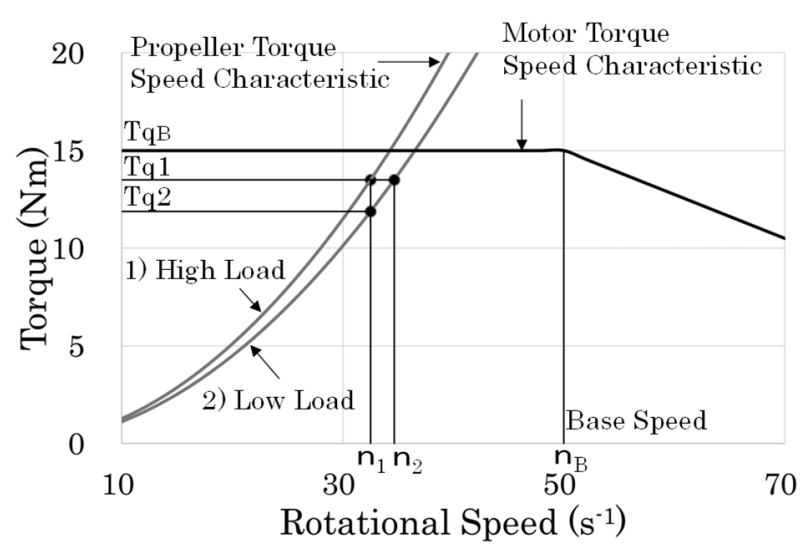

Fig. 2 Torque - Rotational Speed Characteristics

出力されている時, 負荷特性が曲線 1）の場合モータ 回転速度は $n_{1}$ になり。負荷特性が変化して曲線 2) になると, トルクは変動せず, 回転速度が特性曲線 2) 上の回転速度 $n_{2}$ になる. この場合モータ出力は,式 （1）より $T q_{1} \cdot 2 \Pi\left(\mathrm{n}_{2}-n_{1}\right)$ 分上昇することになる ${ }^{7}$.

\section{3. 実験結果と考察}

まず，回転速度一定制御方式の実駼結果を示す。そ の後, 前報 6)7でのトルク一定制御方式での実験結果を 整理して示し，回転速度一定制御方式での実験結果と の比較，相関を検証する. 回転速度一定制御方式にお けるトルク, 回転速度, スラスト, プロペラ周囲の画 像輝度の計測值の一例を Fig. 3 (実験条件: 回転速度 $\left.33.3\left(\mathrm{~s}^{-1}\right)\right)$ に示寸，図の横軸は経過時間を，縦軸の左 軸はトルク $T q$, 回転速度 $n$, 輝度 $B$, 右軸はスラス 卜 Th を表している. 図より気泡の吸込みが発生した タイミングで, トルクが減少し, 同時にスラストも減 少していることがわかる．ここでは，プロペラ周囲気

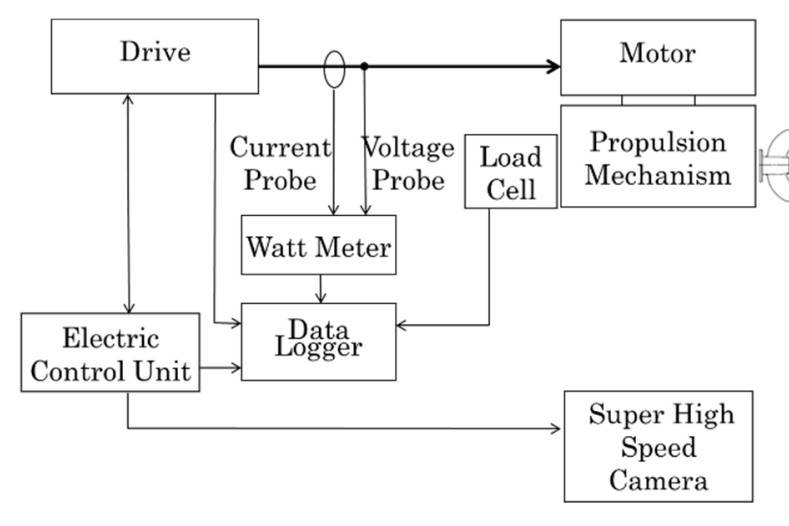

Fig. 1 Block Diagram of Apparatus ${ }^{6)}$

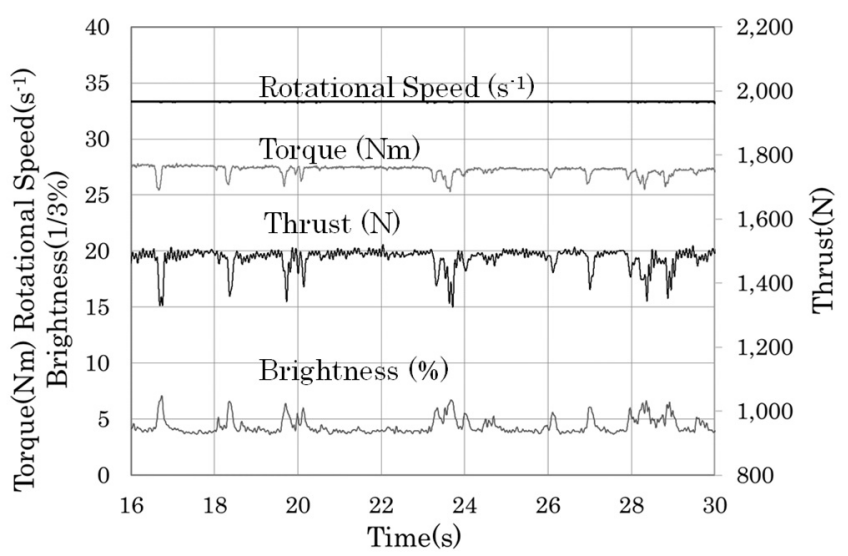

Fig. 3 Measurement Example (Constant Rotational Speed Control ) 
泡状態とプロペラ特性の関係を，理論と実験值に基づ き評価する.

以降の検討では、前報 7)と同様にプロペラ周囲気泡 状態を, 式 (2) により算出されるプロペラ周囲の平均 相対輝度 $B$ をを用いて整理する.

$$
B^{\prime}=\left(B-B_{0}\right) / 100
$$

ここで，Boは，プロペラ周囲気泡が無い場合のプロ ペラ周囲の平均輝度である.

以降の図においてマーカ説明の $-1,-2$ は, 同じ条 件で実験の 1 回目と 2 回目を表している.

\section{1 プロペラ周囲気泡とトルクとの相関}

Fig. 4 に回転速度一定制御方式におけるプロペラ 周囲の平均相対輝度とトルクの関係を示す. 回転速度 の各設定值において, 平均相対輝度 $B^{\prime}$ が大きく((1$\left.B^{\prime}\right)$ が小さく）なるとトルクが減少している。このこ とは Fig. 3 に示寸平均輝度とトルクが連動して減少 していることからも確認できる. 図中の破線は後述す る推定曲線である. ここで, プロペラ周囲の平均相対 輝度の計測值とボイド率が線形の関係にあると仮定す る（詳細は前報 7)）。この仮定を用いて，トルク係数 $K q^{\prime}$ は，プロペラ特性式 11)より次のように表せる.

$$
K q^{\prime}=T q /\left\{\left(1-B^{\prime}\right) \cdot \rho \cdot n^{2} \cdot D^{5}\right\}
$$

ここで， $T q(\mathrm{Nm})$ はトルク， $n$ は回転速度 $\left(\mathrm{s}^{-1}\right), \rho$ は 水の密度 $\left(\mathrm{kg} / \mathrm{m}^{3}\right), D$ はプロペラ径 $(\mathrm{m})$ である. 前報 7) と同様に,これらを式 (3) に代入し得たトルク係数 と平均相対輝度の関係を Fig. 5 に示寸. 図中には前 報 7で得たトルク一定制御時のトルク係数も示した. 制御方式によらず気泡が発生し平均相対輝度が変化し てもトルク係数が一定でかつ一致していることが確認

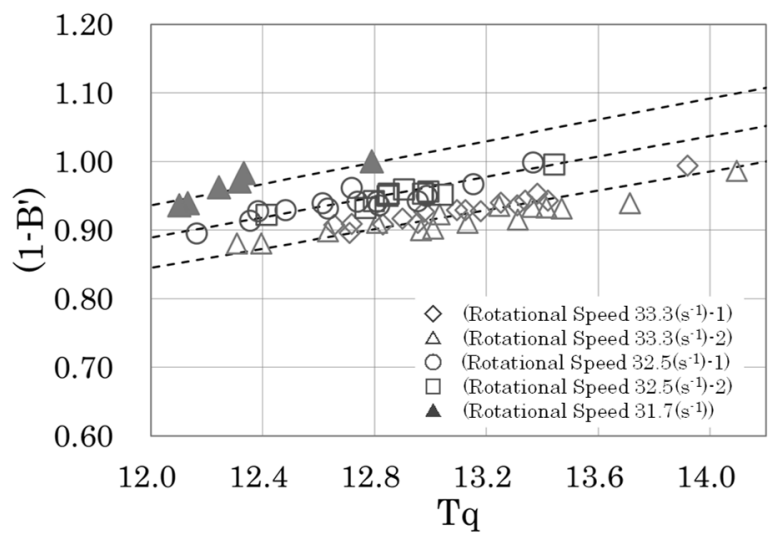

Fig. 4 Correlation between Relative Brightness and Torque

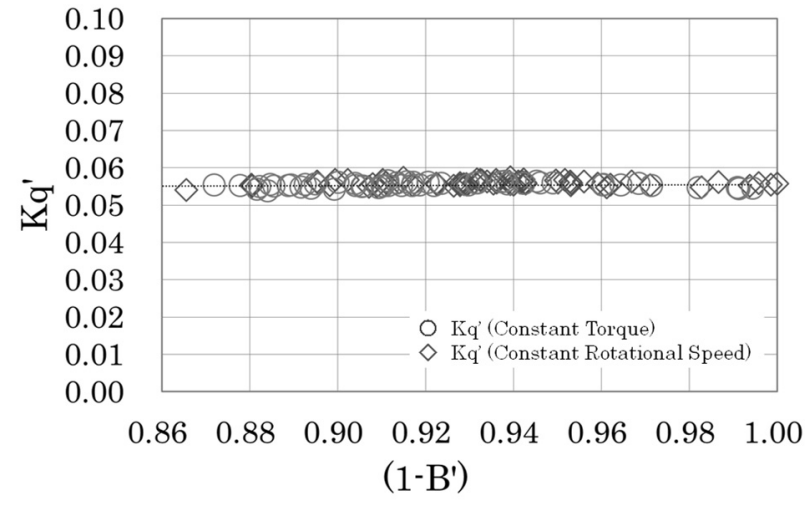

Fig. 5 Torque Coefficient and Relative Brightness

できる。

回転速度一定制御方式における平均相対輝度とトル クの関係は，トルク係数が一定であることから，

$$
\left(1-B^{\prime}\right) \propto T q
$$

と表され，プロペラ周囲気泡状態を示寸平均相対輝度 $B$ 'をトルク $T q$ から推定できる. Fig. 4 の図中の破 線は式（3）を用いた推定值である． $K q^{3} \cdot \rho^{\cdot} \cdot n^{2} \cdot D^{5}$ が 各回転速度設定値により決まる固定値となり，上部か ら回転速度值 $31.7\left(\mathrm{~s}^{-1}\right) ， 32.5\left(\mathrm{~s}^{-1}\right) ， 33.3\left(\mathrm{~s}^{-1}\right)$ を示 している. 図より実験で得られた平均相対輝度は推定 曲線と良く一致していることが確認できる.

\section{2 スラストとトルクとの相関}

スラスト $T h$ とトルク $T q$ の関係は, プロペラ特性

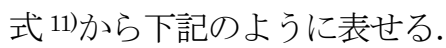

$$
T q / T h=\left(K q^{\prime} \cdot D\right) / K t^{\prime}
$$

ここで， $K t^{\prime}$ はスラスト係数である． 3.1 節よりトル ク係数 $K q^{\prime}$ は一定であり, プロペラ径 $D$ は固定值で ある. 回転速度一定制御方式では，プロペラ周囲気泡 によりトルクが変動することより，

$$
T h \propto K t^{\prime} \cdot T q
$$

と表すことができる.

ここで，スラスト係数を検証する．前報 7) と同様に 計測したトルク，回転速度，平均相対輝度から得たス ラスト係数を Fig. 6 に示す。図中に前報》で得たトル ク一定制御時のスラスト係数も示した. 平均相対輝度 $B$ ’゙大きく((1-B') が小さく) なるとスラスト係数は 減少し，制御方式によらずスラスト係数が一致してい 
ることが確認できる.

次に, 式 (5) で計算したスラストと, 計測したスラ ストの相関を Fig. 7 に示す. さらに式 (5) において スラスト係数を平均值 $K t^{\prime}=1.102$ に固定した場合の スラストと計測したスラストの相関を Fig. 8 に示寸. 回転速度一定制御では，スラスト変動はトルク変動の 影響が支配的であるが，スラスト係数の影響も Fig.7

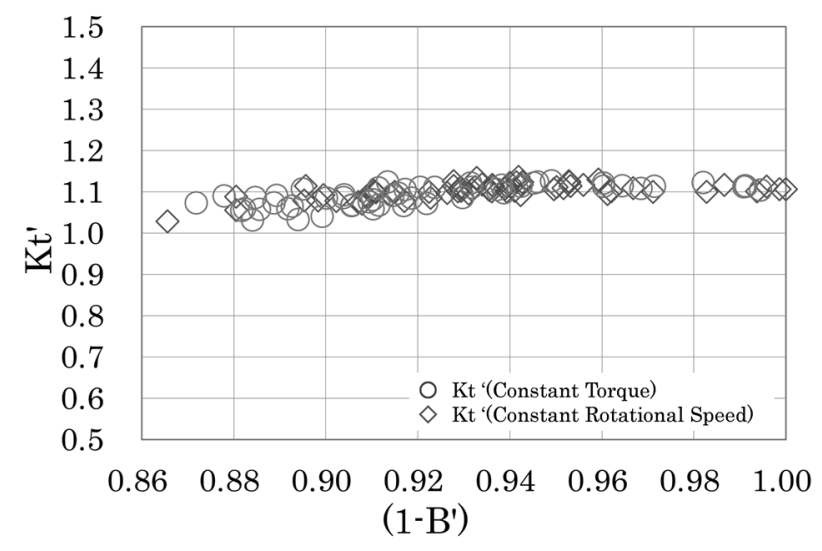

Fig. 6 Thrust Coefficient and Relative Brightness

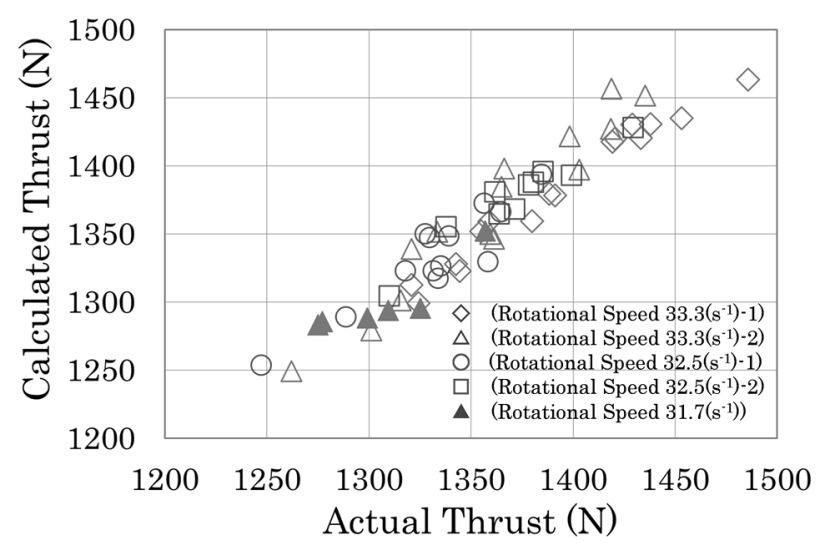

Fig. 7 Comparison between Actual Thrust and Calculated Thrust

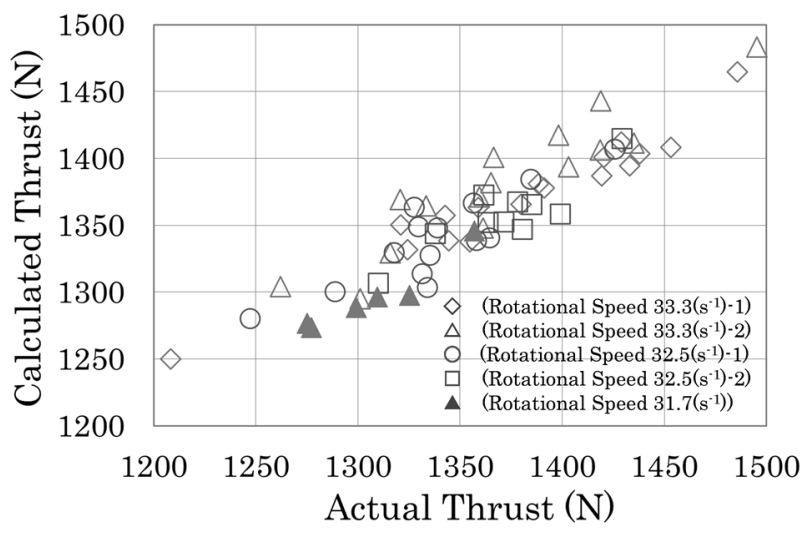

Fig. 8 Comparison between Actual Thrust and Calculated Thrust $\left(\mathrm{Kt}^{\prime}=\right.$ constant $)$
と Fig. 8 の比較から確認できる. 以上により回転速 度一定制御におけるスラストの計測值と理論式がほぼ 一致していることが確認できる.

以上，回転速度一定制御方式について検証した。 こ こでは，前報 7)で検証したトルク一定制御方式との比 較を行う。トルク一定制御方式での，平均相対輝度と の相関，スラストとの相関を下記に示す。

トルク一定制御では, 式 (3) よりトルク $T q$ 及びト ルク係数 $K q$ ’ が一定であり, 水の密度 $\rho$ とプロペ ラ径 $D$ は固定值であるので次のように表せる.

$$
\left(1-B^{\prime}\right) \propto 1 / n^{2}
$$

さらに，式（8）で表されるスラストは，式（7）より $\left(1-B^{\jmath}\right) \cdot n^{2}$ が一定であることから, 式 (9) と表せる.

$$
\begin{aligned}
& T h=K t^{\prime} \cdot\left(1-B^{\prime}\right) \cdot \rho \cdot n^{2} \cdot D^{4} \\
& T h \propto K t^{\prime}
\end{aligned}
$$

式 (7) より回転速度 $n$ は平均相対輝度の平方根に 反比例することになり，4.1 節で述べるプロペラ周囲 気泡によるモータ出力が増加の方向に変動することを 示している. 式 (4) で示寸回転速度一定制御方式では, トルクが平均相対輝度に比例しているので，モータ出 力が減少の方向に変動することを示している，スラス トにおいては，回転速度一定制御方式は式 (6) で示寸 ようスラスト係数とトルクの乗算に比例するが，トル ク一定制御方式では式 (9) に示すようスラスト係数 のみに比例しているので，スラストへの影響は，トル ク一定制御方式のほうが少ないといえる．スラスト係 数の減少は，気泡の混入によりプロペラ翼面における 壁面せん断応力が低下し，それに起因してプロペラ特 性が変化したことによると考えられる7．スラストの 変動の比較に関しては, 4.1 節で述べる.

\section{4. 制御方式の比較と考察}

回転速度一定制御方式とトルク一定制御方式におい て，それぞれの制御方式で，プロペラ周囲気泡による モータ出力変動の挙動は異なり, スラスト変動の挙動 も異なる。これらの違いを，モータドライブからのモ ニター信号と理論式から検証し考察する．回転速度一 定制御方式とトルク一定制御方式の実験装置，実験環 境に差異がないことを, 3.1 節と 3.2 節にて, それぞ れの制御方式のトルク係数とスラスト係数が一致して いることから確認している. 


\section{1. 制御方式によるモータ出力変動の比較検証}

プロペラ周囲気泡によるモータ出力において，回転 速度一定制御方式は, 式 (1) と式 (4) により, モ一夕 出力 $P r \quad(\mathrm{~W})$ は, 以下の式で表せる.

$$
\operatorname{Pr} \propto\left(1-B^{\prime}\right)
$$

すなわち, プロペラ周囲気泡によるモータ出力は平均 相対輝度に比例して変動寸る．一方，トルク一定制御 方式では, 式 (1) と式 (7)によりモータ出力 Pt (W) は，以下の式で表せる.

$$
P t \propto 1 / \sqrt{ }\left(1-B^{\prime}\right)
$$

ここでは，プロペラ周囲気泡によるモータ出力は平均 相対輝度の平方根に反比例して変動する.

次に, モータ出力と平均相対輝度の相関を検証する. 計測したトルクと回転速度を式（1）に代入して, モー 夕出力と平均相対輝度の相関を得る. 回転速度一定制 御方式のモータ出力変動を Fig. 9 に示寸. 図中の推定 曲線（破線）は，式 (3) より求めたトルク $T q$ を式 （1）に代入して得ており, モ一タ出力が, 平均相対輝度 に比例している. 一方, Fig. 10 は，トルク一定制御方 式のモータ出力と平均相対輝度の相関を示している. 図中の推定曲線(破線)は，回転速度一定制御方式と同 様に式（3）を用いて求めた回転速度 $n$ を式（1）に 代入して得ている. モ一タ出力が平均相対輝度の平方 根に反比例している. これら計測したモータ出力が, 推定曲線とよく一致しているのが確認できる.

以上より，回転速度一定制御方式では，モータ出力 は, 平均相対輝度と線形の相関で変動し, 平均相対輝 度が大きくなると減少する. トルク一定制御方式では 平均相対輝度と指数関数の相関で变動し平均相対輝度

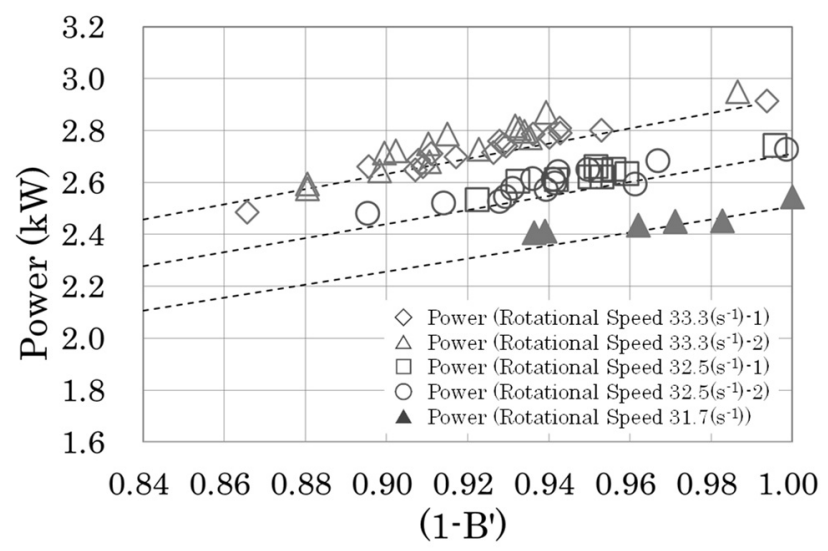

Fig. 9 Correlation between Relative Brightness and Power ( Constant Rotational Speed Control)
が大きくなると上昇する．推定式では平均相対輝度が 0.6 までは，トルク一定制御方式のほうが回転速度一 定制御方式よりモータ出力変動量は少なくなる. 次に, プロペラ周囲気泡によるモータ出力変動量の比較を行 う.気泡のない状態でのモータ出力差が $2 \%$ 以内の回 転速度一定制御方式 ( $2.78 \mathrm{~kW})$ とトルク一定制御方 式 ( $2.73 \mathrm{~kW})$ のモータ出力変動量の比較を Fig. 11 に示した. $\left(1-B^{\prime}\right)=0.894-0895$ における出力変動に 着目寸ると，トルク一定制御と回転速度一定制御のモ 一タ出力変動量は, それぞれ $0.2 \mathrm{~kW}$ と $0.3 \mathrm{~kW}$ であ り, 回転速度一定制御の方が 1.5 倍大きいことが確認 できる.

次にスラスト変動について示寸. Fig. 12 は, 上記モ 一タ出力変動量の比較で用いたモータ出力における回 転速度一定制御方式とトルク一定制御方式のスラスト 変動の例を示している. プロペラ周囲気泡発生により 起こるスラストの変動量に差があることが分かる。 こ れらを以下で検証する.

回転速度一定制御方式では, 式 (4) に示すようプロ ペラ周囲気泡により，トルクは平均相対輝度 $B^{\prime}$ が大

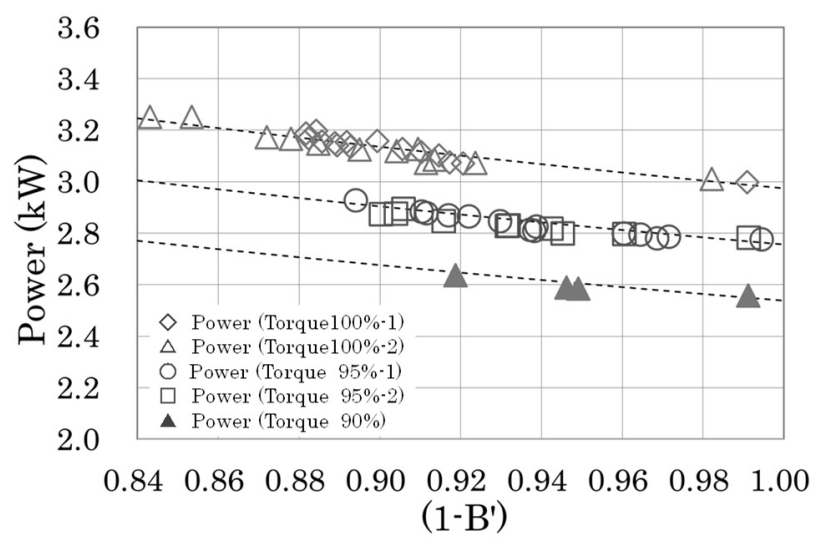

Fig. 10 Correlation between Relative Brightness and Power ( Constant Torque Control )

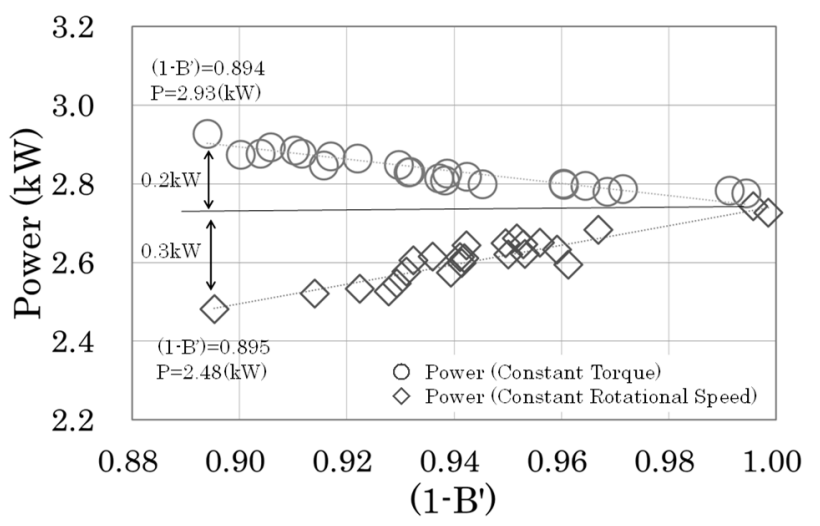

Fig. 11 Correlation between Relative Brightness and Power 


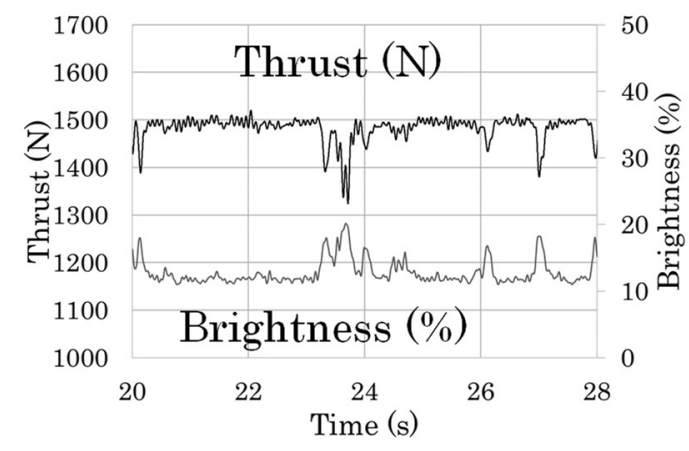

Constant Rotational Speed Control

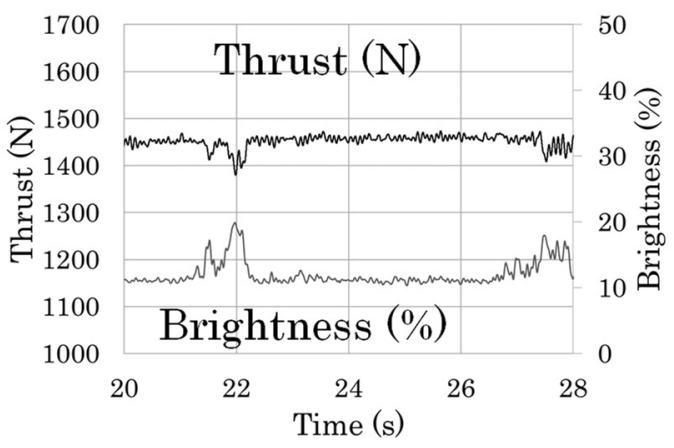

Constant Torque Control

Fig. 12 Thrust variation

きく ((1- $\left.B^{\prime}\right)$ が小さく $)$ なると減少し, 3.2 節に示寸 ようスラス卜係数 $K t^{\prime}$ も，平均相対輝度 $B$ 'が大き く((1-B') が小さく) なると減少する. 寸なわち, ス ラスト変動は, 式 (6) に示寸ようスラスト係数とトル クの乗算に比例して減少する. 一方，トルク一定制御 方式では, 式 (9) に示すようスラスト変動は, スラス 卜係数に比例する. Fig. 13 は, Fig. 11 と同じ出力に て，平均相対輝度に対するスラストの変動量の比較を 示している. モータ出力変動と同様に, $\left(1-B^{\prime}\right)=0.894-$ 0895 におけるスラスト変動に着目寸ると,トルク一定 制御と回転速度一定制御のトルクの変動量は, それぞ れ $0 \mathrm{Nm}$ と $1.29 \mathrm{Nm}$ であり, スラスト変動量は, そ れぞれ $93 \mathrm{~N}$ と $183 \mathrm{~N}$ である. スラスト変動量は, 回転 速度一定制御の方が，トルクの変動がないトルク一定 制御より 2.0 倍大きいことが確認できる. トルク倸数 のみに比例するトルク一定制御に比べ，スラスト係数 とトルクの乗算に比例する回転速度一定制御方式のほ うがスラスト変動量が大きくなる. 理論式で示寸差異 があることが確認できる.

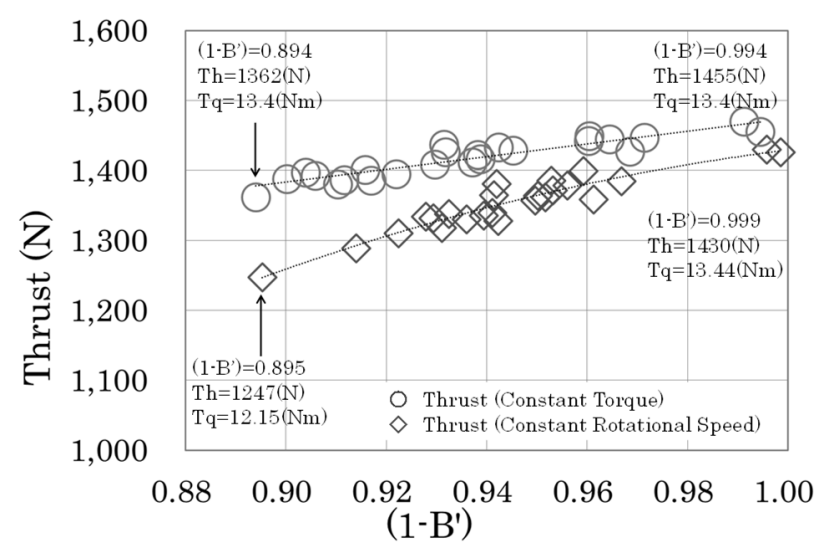

Fig. 13 Correlation between Relative Brightness and Thrust

\section{2. 制御方式に関する考察}

以上より, 同じ出力で運転時にプロペラ周囲気泡が 発生した場合, 気泡の影響によるモータ出力変動は, 回転速度一定制御では出力減に変動し, トルク一定制 御では出力増に変動する．気泡が一定範囲内では回転 速度一定制御のほうが変動は大きくなる．また，スラ ストへの影響も, トルクが減少する回転速度一定制御 のほうが大きくなる. A. J. Sørensen らの報告におい てもトルクコントローラは, 流入の乱れによる推力損 失の補償に関して優れているとしている12).

最後に, Table. 1 にモータ制御方式による各種相関 を整理して示す.

Table. 1 Various Correlations by Control Method

\begin{tabular}{|c|c|c|}
\hline & $\begin{array}{c}\text { Constant Torque } \\
\text { Control }\end{array}$ & $\begin{array}{c}\text { Constant } \\
\text { Rotational Speed } \\
\text { Control }\end{array}$ \\
\hline $\begin{array}{c}\text { Relative } \\
\text { Brightness }\end{array}$ & $\left(1-B^{\prime}\right) \propto 1 / h^{2}$ & $\left(1-B^{\prime}\right) \propto T q$ \\
\hline Motor Power & $P t \propto 1 / \sqrt{ }\left(1-B^{\prime}\right)$ & $P r \propto\left(1-B^{\prime}\right)$ \\
\hline Thrust & $T h \propto K t^{\prime}$ & $T h \propto K t^{\prime} \cdot T q$ \\
\hline
\end{tabular}

これらにより，回転速度一定制御とトルク一定制御 とでは, プロペラ周囲気泡によるモータ出力変動の挙 動とスラスト変動の挙動が異なることを, モータドラ イブからの信号を用い，プロペラ特性式とモータ特性 式から理論的に示した.

\section{5. 結論}

本報告では, 前報 6)7において示したトルク一定制御 方式での実験結果を整理して示し，回転速度一定制御 方式での実験結果との比較，相関を検証した．また， 
双方の制御方式におけるモータ出力変動とスラスト変 動を比較，検討した.

1）回転速度一定制御方式での実験は，トルク一定制御 方式での実験と同じ装置を用い，同じ環境にて，モー タ推進装置を駆動し，モータドライブから計測した回 転速度モニター信号，トルクモニター信号とプロペラ 特性式を用いて，これらの実験結果を理論的に検証し 次の結果を得た。

i）回転速度一定制御においても, 前報7)のトルク一 定制御時と同様に，プロペラ特性式より実験で得られ たモータドライブからの計測值と平均相対輝度の相関 を良く説明できる.

ii） i）と同様に, プロペラ特性式よりスラストとス ラスト係数とトルクの相関を良く整理できる.また, 回転速度一定制御では，プロペラ周囲気泡によりスラ ストは，スラスト係数とトルクの乗算に比例して変動 する.

2）回転速度一定制御方式とトルク一定制御方式にお いて，プロペラ周囲気泡によるモータ出力変動とスラ スト変動の挙動の違いを，モータドライブから得たモ ニター信号と理論式を用い検証し次の結果を得た。

i）回転速度一定制御方式では. 気泡の発生に従いモ 一夕出力は, 平均相対輝度に比例して出力減に変動す る. トルク一定制御方式では, 平均相対輝度の平方根 に反比例して出力増に変動する. 同じ出力の運転にお いて，モータ出力変動量は。気泡が一定範井内におい て, 平均相対輝度の平方根に反比例するトルク一定制 御の方が少ない。

ii）スラスト変動において, 回転速度一定制御方式で は，スラスト係数とトルクの乗算に比例し，トルク一 定制御方式は，スラスト係数に比例する. 同じ平均相 対輝度によるスラストへの影響は，トルクの減少を伴 う回転速度一定制御方式の方が大きい.

以上これらのことをモータドライブからのモニター 信号とプロペラ理論式から説明できることを示した. すなわち，モータドライブのモニター信号は，その制 御方式によらずモータ出力変動及びスラスト変動を制 御するために用いるセンシング信号として期待できる. また，荒天時航行などプロペラ周囲気泡が発生する場 合には，トルク一定制御が優位と考えられる．モータ ドライブからの信号を解析し, 回転速度一定制御と卜 ルク一定制御の切替えを適時に行うことで最適な運転 が期待できる.

この研究の一部は, 日本学術振興会科学研究費補助金 （16H02431）の支援を受けた.

\section{References}

1) S. D. Black, Thrust Breakdown Characteristics of Conventional Propellers, (2007), NSWCC-5-TR-2007/064.

2) K. Koushan, S. Spence, L Savio, Ventilated Propeller Blade Loadings and Spindle Moment of a Thruster in Calm Water and Waves, Second International Symposium on Marine Propulsors smp'11, Hamburg, Germany, June 2011.

3) A. M. Kozlowska, K. Wöckner, S. Steen, T. Rung, K. Koushan, S. J. B. Spence, Numerical and Experimental Study of Propeller Ventilation, Second International Symposium on Marine Propulsors smp'11, Hamburg, Germany, June 2011.

4) M. Uchida, K. Teshima, Y. Matsumoto, T. Wakamatsu, Cavity Formation and Bearing Force by Air Ventilation on Marine Screw Propeller, Journal of the Japan Society of National Architects and Ocean Engineers (2007), pp. 297304.

5) A. Califano, S. Steen, Numerical Simulations of a Fully Submerged Propeller Subject to Ventilation, Ocean Engineering 38 (2011), pp. 1582-1599.

6) T. Ode, T. Takamasa, E. Shimizu, T. Hazuku, H. Kifune, T. Thara, Detection of Near-Propeller Bubbles and Thrust Power in a Constant Torque Control Motor Propulsion System, Proceedings of Journal of the JIME, Vol. 53, No. 3 (2018), pp. 89 - 94.

7) T. Ode, T. Takamasa, T. Hazuku, T. Thara, Characterization of Near-Propeller Bubbles and Thrust Fluctuation in a Constant Torque Control Motor Propulsion System, Proceedings of Journal of the JIME, Vol.53, No.4 (2018),pp. 111-116.

8) F. Hu, T. Tokai, S, Takeda, D, Shiode, H. Inada, Y. Hashizume, The Performance of New Circulating Water Channel of Tokyo University of Marine Science and Technology, Fisheries Engineering, Vol. 41, No. 2 (2004), pp. 153-163.

9) A.V. Oppenheim and R.W. Schafer, Discrete-Time Signal Processing, 3rd Edition, (2009), Pearson.

10) K. Hirota, S. Adachi, Y. Deguchi, S. Ogasawara, Model-Based Control Systems Design for Electric Vehicles, (2009), Tokyo Denki University Press.

11) S. Ogiwara, S, Yamazaki, Y. Yoshimura, H. Adachi, SENPAKU SEINO SEKKEI, (2013), The Japan Society of Naval Architects and Ocean Engineers.

12) A. J. Sørensen, Ø. N. Smogeli, Torque and Power Control of Electrically Driven Marine Propellers, Control Engineering Practice 17 (2009), pp. 1053-1064. 